International Journal of Advanced Academic Studies 2019; 1(1): 222-224

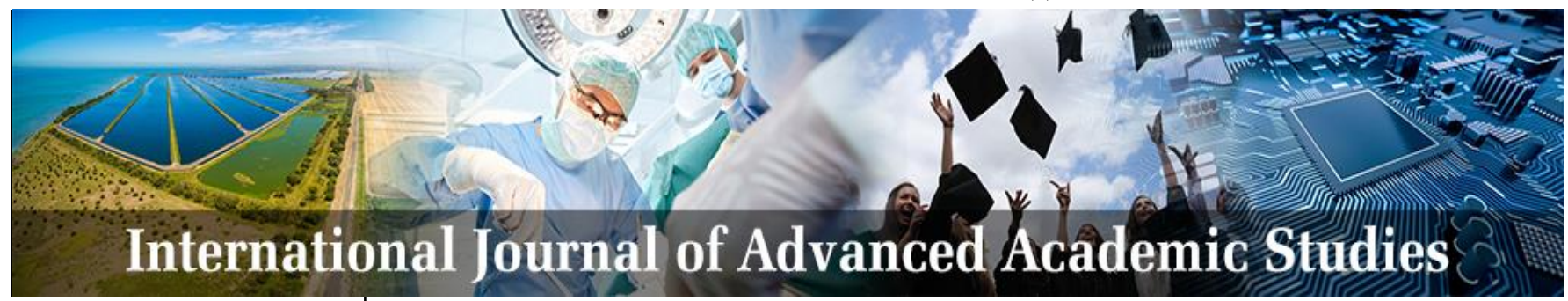

E-ISSN: 2706-8927

P-ISSN: 2706-8919

IJAAS 2019; 1(1): 222-224

Received: 20-05-2019

Accepted: 25-06-2019

Dr. Sudhir Kumar Rawat Associate Professor, Department of Zoology, Government Degree College Kasganj, Uttar Pradesh, India

Anjana Vashishtha

K.A.P.G. College, Kasganj, Etah, Uttar Pradesh, India

Corresponding Author: Dr. Sudhir Kumar Rawat Associate Professor, Department of Zoology, Government Degree College Kasganj, Uttar Pradesh, India

\section{Philosophy of some hymns of vedas and purans in relation to environmental status}

\author{
Dr. Sudhir Kumar Rawat and Anjana Vashishtha
}

DOI: https://doi.org/10.33545/27068919.2019.v1.i1a.648

\begin{abstract}
Universe is full of mysterious and man in the unique creation of the universe. The universe attract the attention of all the sensitive minds towards its changing order, and orderly changes fascinated philosophers to think about role of nature: Philosophy is an endeavour to comprehended the ultimate nature of the Universe through speculations. Different religions prevailing have environmental overtones and an ecological code of conduct for reverence towards nature and natures' creation. As the following has been mention in Kishindakanda kand (Chaupai No.-2) in the Ramcharitmanas. Kshiti jal pawak gagan sameera. Lord Rama explain that the five things the Prithvi (earth), the water, the fire, the sky (cosmos) and the air make the human body. As our lord said that these five adiotic factors are responsible for making our body its' our responsibility to preserve these factors and it has been advised to worship them which make our environment clean and healthy. In the hymns of Regvedas it has been advise not to disturb the Sky and do not pollute the atmosphere. Dhyan ga lekhirantariksha mahiesih prithavi sambhav ayamprahi twa... Care for the nature and natural creations were given great importance during ancient times in India. The need of the time to preserve our wild life and thereby to help in maintaining the ecological balance.
\end{abstract}

Keywords: hymns, vedas, purans

\section{Introduction}

The Vedic literature gives us the genuine principles to adjust with our environment and lead a spiritual life full of bliss. The Veda specially has dealt in detail about various aspects of environment and showed more concern for ecology. Most of the environmental problems of the present day are essentially man made. The role of man is therefore important for shape the environment in perfect harmony. So the proper following of the Vedic techniques, methods and principles and the new knowledge generated through science and technological research should be employed to save the human beings from environmental degradation.

\section{The objectives of the research paper}

1. To find out the environmental preservation reflected in the Vedic literature and

2. To highlight the relevant of these thoughts in present time.

According to Hindu mythology Lord Bharma is believed as Creator of the Shrushti (Universe), Lord Vishnu as the Operator of the Shrushti and Lord Mahesh (also known as Lord Shiva) as the Destroyer of the Shrushti. Here the Shrushti means the entire Universe involving all the living and non-living creatures. Ancient Hindu mythology believes that the universe is made up of Panchamahabhutas - physical creation five Great Elements composed of Akash (Ether), Vayu (Air), Agni (Fire), Jala (water) Prithvi (Earth) ${ }^{[2]}$. Atharva Veda in its Eighth Chapter, tenth Sukta, First Shlokas mentions about origin of Universe (Shrusthi):

\section{Viradvaidmagraaasittasyajatyah sarvamvibhediyamevedambhavishyateeti}

It means, there was gigantic power before the Shrusthi. It is known as Eternal Power. It is believed that Shrusthi originated out of this Eternal Power, this Eternal Power lies in every life on Shrushti. Further in its Ninth Chapter, First Sukta, First Shlokasit narrates that Cow (Gau Mata) is originated from Heaven, Earth, Ether (Solar System) and Sea 


\section{Divasprithivya antarikshatsamudradgravartanmadhukshahijagye}

The Vedic hymn, in Atharva Veda BhumiSuktais dedicated to the Goddess Earth is unquestionably the oldest evocative environmental invocation, is a sacred text. The BhumiSuktais described in Twelfth Chapter First Sukta in Sixty-Three Shlokas. He Mother Earth was celebrated for all her natural bounties and particularly for her gift of herbs and vegetation, her blessings were sought for prosperity in all endeavours and fulfilment of all righteous aspirations ${ }^{[9]}$. Atharva Veda Ninth Chapter, Tenth Sukta, Twelfth Shlokas recognizes Earth as Mother Earth: mata prithavi maheyam

\section{The environment in veadas hymn}

We have four Vedas 'the Rig, Sama, Yajur and Atharva' recognize. These Vedas Shloks are teaching us conservation environmental ethics. During the Vedic times people are regards the environment and use conservation ethics in routine life. Some points are ....

'Do not harm the environment, do not harm the water and the flora, earth is my mother, I am her son, may the waters remain fresh, do not harm the waters--. Tranquility be to the atmosphere, to the waters, to the crops and vegetation.'

"mātā bhūmih putruahan pṛthivyā:",

This Vedic prayer invokes divine intervention to bliss and protect the environment. To protect environment the Rig Veda says-

"madhu vātāḥ ritāyate madhu kṣaranti sindhavah mādvih nạ̣ santuṣadhi. madhu naktamutusāsu madhumatpārthiva rajah madhu kṣorastu suryah mādhirgābo bhavantu nặ", (Rigveda,1/90/6,7,)

Means: Environment provides bliss to people leading their life perfectly. Rivers bliss us with sacred water and provide us health, night, morning, vegetation. Sun bliss us with peaceful life. Our cows provide us milk). The plant ecology has a great importance to keep the environment in balance. The Vṛkșāyurveda says that planting a tree is equally beneficial as having ten son-

“dasakūpa sama vāpi dasa vāpi sama hradaḥ dasahrada samah putro dasaputra sama drumah"

(Vrksayurvedah-5).

Tulshi, Pippala and Vatavṛkṣa have great importance in our culture. About the importance of Tulashi, Vatavṛsșha there are many slokas are found in the vedic literature. Some of them are-

“jābadināni tulashi rūpitāpi jad gṛihe grihe. tābadvarṣha sahasrāni vaikunthe sa mahīyate"'

(Vṛkṣhāyurveda-9).

The fire and Sun play the most significant role in the purification of environment. Animals and birds are part of nature and environment. The Vedic seers have mentioned about their characteristics and activities and have desired their welfare. Rig-Vedic seers classifies them in three groups sky animals like birds, forest animals and animals in human habitation-

"tasmat yajnat sarvahutah samvrtan prsadajyan pasuntansakre vayabyanaranyan grāmyasca ye."

(Rigveda, 10/90/8)

Protection of birds, animals is a norm of Hindu religion. The Hindu mythology believes fourteen avataras (births) of the god like Matsya, Kurma, Varaha, Nrisingha etc. signify the devine forms in such animals and thereby making their life secure. The cobra is worshipped on the eve of Nagpanchami and cows are offered adoration on the occasion of the Balabhadrapuja. Killing of certain animals and birds who acted as scavengers by feeding on carcasses and filth was religiously banned according to the Vedas. It is need of the day to follow in the root steps of the ancient period-

"kincideva tu vipryāya dadyadasthimatan vadhe.

Anasthanancaiva himsayah pranayamena śudhyati.',

(Manu -samhita-11/142)

In the Bhagavad Gita, lord Krishna says that "this Prakriti of mine is divided eight fold thus: earth, water, fire, air, space, mind, intellect and also egoism.

Bhumir apo'nalo vayuh kham mano buddhir eva ca ahaikara itiyam me bhinna prakrtir astadha.

The environment required for the survival of human beings consists of two aspects, i.e. external and internal. The external aspects include earth, water. Air, fire and space whereas internal aspects include mainly mind.

Atharvaveda's love for earth is outstanding (Prithivisukta) as mother earth bestows love on all creatures living on it. In it, the Vedic seer solemnly declares the enduring filial allegiance of human kind to Mother Earth: "mata Bhumih Putrohom Prirhivyah" [7], Earth is my mother, I am her son. "Mother Earth" is deliberated for all her natural bounties and particularly for her gifts of herbs and vegetation. Her blessings are sought for prosperity in all surroundings and fulfillment of all righteous aspirations. A convenient is made that human kind shall secure the Earth against all environmental trespass and shall near let her be oppressed. A soul-string prayer is sung in one of the hymns for the preservation and conservation of hills, snow-clod maintains, and all brown, black and red earth, unhurt, unwounded, unbroken and well defended by India.

Today, we need a communion that our heart be wide enough so that no one is excluded as all of them have a well defined subtle role to build up ecological capital and to maintain the balance in nature.

Sita Bhumir Asima Pamsuh, Sa Bhumih Samdhrta Dhrta.

Earth bestows on us with minerals, gold, silver etc. We bow in reverence to mother earth. We should not unnecessarily dig the earth as laid down in 35th Mantra of Bhumisukta. (Yat me Bhume Visvanabhi Tadepi Sohatu Ma Te Marma Vinmgvadi Ma te hrdeyanapimam). Purity of atmosphere checks pollution. In this reference there is a Mantra in Atharvaveda 
Sarvo Vai Tatra Jivate

Gour - Asvah Purusah Pasuh

Yatredam Brahma Kriyate

Paridhir Jivantaya kam.

"Everyone, whether a human being or an animal, lives safely, where the purity of atmosphere (Bhahman) is maintained all around for the purpose of life." The Vedic people desired to live a life of hundred years and this wish can be fulfilled only when environment will be unpolluted, clean and peaceful.

The knowledge about the origin and significance of plants can be traced out from Vedic literature. Plants are savior of humanity. They possess qualities of all deities. The plants and herbs destroy poisonous effect of the atmosphere. There is a Mantra in the Atharvaveda that some herbs cure diseases and purifies the air.

\section{Na Tam yaksma Arundhate \\ Yam Bhesjasya Gulgulah, \\ Surabhin Gandho asnute.}

One of Rgvedic hymn says that don't cut the trees, because they remove pollution 'ma kakambiram ud vrho vanaspatim, as astir vi hi ninasah.

\section{References}

1. Patra DB. Environment In Early India: A Historical Perspective, Environment: Traditional \& Scientific Research 2016;1(1):39-56.

2. CKG, Rajan AP. Ecocentrism in India: An Incredible Model of Peaceful Relation with Nature, Universal Journal of Environmental Research and Technology 2014;4(2):90-99.

3. State of Forest Repot 2017, Forest Survey of India (Ministry of Environment \& Forests), Dehradun 2017.

4. Bhattacharya S. Forest and biodiversity conservation in ancient Indian culture: A review based on old texts and archaeological evidences, International Letters of Social and Humanistic Sciences 2014;30:35-46.

5. Krishna N. Hinduism and Nature, Gurgaon, Haryana: Penguin Random House India 2017, 21.

6. Vidyasagara J, Matsya Purana. Kolkata 1876.

7. Gupta S. Environment Ethics, Policies and Inclusive Environment Protection Mechanism in India (With Special Reference to Environmental Inquisition), Journal of Environment and Earth Science 2015;5(3):112-118.

8. Tirth V, Atharva Veda, Delhi: Manoj Publications 2018.

9. Cabinet U. National Environment Policy 2006, Delhi: Government of India, Ministry of Environment and Forest 2006.

10. MoNRE G. Generation of Solid Waste Question No. 2974, in Lok Sabha Unstatted Question No. 2974, New Delhi 2018.

11. Sarkar DN. Environmental Policy in India, ARSS 2014;3(2):17-20.

12. Reddy DR. Environmental Policy Transformation In India - A Historical Metamorphosis, North Asian International Research Journal of Social Science \& Humanities 2017, 3(4).

13. Kandwal NP. Green India and environmental legislation, ESSENCE - International Journal for
Environmental Rehabilitation and Conservation 2017;8(1):46-50.

14. Narula SDSA. Corporate Social Responsibility in India-Introspection, Journal of Mass Communication \& Journalism 2015;5(7):5-7.

15. WCED. Report of the World Commission on Environment and Development: Our Common Future, Oxford University Press 1987. 